\title{
Spectrophotometric Determination of Mefenamic Acid in Pharmaceutical Preparations Via Arsenazo III - Cerium (III) Reaction*
}

\author{
Nabeel S. Othman \\ Lena S.Awadis \\ Department of Chemistry \\ College of Science \\ Mosul University
}

(Received 23/6/2008; Accepted 10/11/2008)

\begin{abstract}
A sensitive indirect spectrophotometric method is proposed for determining mefenamic acid in pure form and in its pharmaceutical preparations. The method is based on oxidation-reduction reaction between mefenamic acid and cerium (IV) ion, and subsequent $\mathrm{Ce}$ (III) reaction with arsenazo (III) reagent in acidic medium to produce a greenish-blue complex which is stable, water soluble and has a maximum absorption at $654 \mathrm{~nm}$ with a molar absorptivity of $1.731 \times 10^{5} 1 . \mathrm{mol}^{-1} . \mathrm{cm}^{-1}$. Beer's law is obeyed in the concentration range from 1 to $10 \mu \mathrm{g}$ mefenamic acid in a final volume of $25 \mathrm{ml}$. The proposed method has been applied successfully to determine mefenamic acid in pharmaceutical preparations.
\end{abstract}

\section{القير اللافي لحامض المفيناميك في المستحضرات الصيدلانيه بلستخدلم فالل الارسين انو الثلايثمع الميريوم الثلاثي}

\section{الملغص}

مَ اقتراحطريقةطيفية غيرمبلثرة ومسلسة لققير ح لمض المفينلمي لك بـ شكله الق مي وف مي مستحضراته الدوائيه. اعتمدت الطاريقة على قفاعل الأكسة والختزل بين حلمض الميفينمي لك ولي -ون للسيريو الرباعي يتبعها مفاعلة ناتج الفاعل أيون للسيريوم الثلاثي مع الكلثف آسسن آزو III في وسط يبن

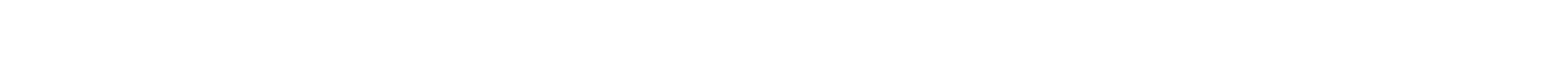

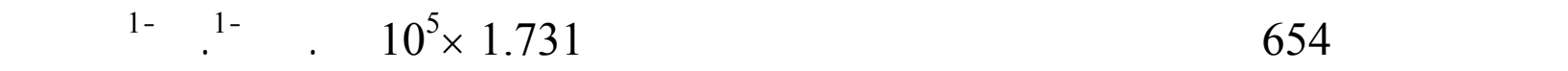
قانون بير في مدى التركيز بين 1 و10 مايكروغرلم من حلمض الميفينلميك في حجم نهائي 25 مل. ت م ظبيق الطريقة المقترحة بنجاح في تقدير حلمض الميفينميك في مستحضراته الدوائية.

*م إقاهه بالمؤتمر العلهي الأول للكيمياء المنعقد بتاريخ 22-23 نيسلن 2008 فى قسم الكيمياء /كلية العلوم/جلمعة الموصل 


\section{INTRODUCTION}

Mefenamic acid [2-(2,3-dimethyl phenyl)amino]benzoic[I] acid is a non-steroidal anti-inflammatory drug which has analgesic, anti-inflammatory and antipyretic actions. It is used specially in the treatment of rheumatoid arthritis, osteoarthritis and other muscular-skeletal diseases (Martindale, 1982).

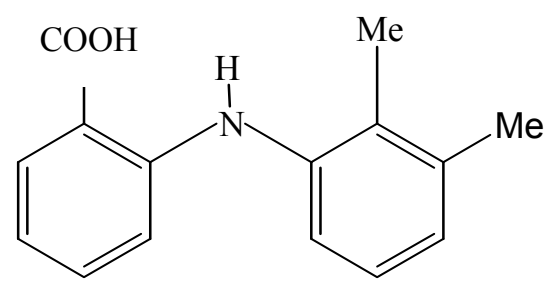

[I]

The standard method for the assay of the pure drug is titrimetry, using sodium hydroxide as a titrant and phenol red as indicator (British pharmacopia, 2000).

Different techniques have been described for the determination of mefenamic acid: High performance liquid chromatography has been used for the determination of the drug in biological fluids such as human plasma (Niopas and Mamzoridi, 1994) or in human serum (Mohammed et al., 2004), and in horse plasma (Ishidaka et al., 1986).

Terbium sensitized fluorescence is used to develop a sensitive spectrofluorometric method for determination of mefenamic acid (Pinclopi et al., 1998), another spectrofluorimetric method based on oxidation of mefenamic acid with cerium (IV) (Tabrizi, 2006 ).

Flow- injection technique was used in the determination of mefenamic acid, the methods based on formation of complex with Al(III) (Albero et al., 1995), tris (2, ,$\overline{2}$ bipyridyl) ruthenium (III) (Fatma et al., 2000).

Several spectrophotometric methods have been reported for the estimation of mefenamic acid using different reagents such as diazotised 4-amino-3,5dinitrobenzoicacid (Idowut et al., 2003), methyl-2-benzo-thiazolinone hydrazone hydrochloride after oxidation with $\mathrm{Ce}^{+4}$ or $\mathrm{Fe}^{+3}$ (Chilukuri et al., 1989), sodium nitroprusside in the presence of hydroxyl ammonium chloride (Sastry and Rao, 1987), pdimethylaminobenzaldehyde (Aman et al., 2005), p-dimethylaminocinnamaldehyde (ElSherif et al., 1997), triton X-114 (Tabrizi, 2006), $\mathrm{Fe}^{+3}$ to form coloured complex (Zommer and Bojarowicz, 1986).

Many methods have been used in simultaneous determination of mefenamic acid in the presence of another drug such as paracetamol (Dinc et al., 2002 ), ethamsylate (Garg and Saraf, 2007).

However some of these procedures suffer from one or another disadvantage such as: the product may be extracted to organic solvent (Idowut et al., 2002), or require nonaqueous medium (El-Sherif et al., 1997) and other required control of temperature (Aman et al., 2005, Tabrizi, 2006).

Arsenazo (III) undergoes sensitive and selective reactions with several cations, such as reaction with cerium (III) ion in the presence of cerium (IV) ion. This reaction can be used in the determination of some organic compounds which have the ability to undergo 
oxidation-reduction reaction with cerium (IV) ion (Al-Irhayim, 2004; Al-Abdaly, 2005; Jaime and William, 1991).

The objective of investigation reported in this paper is to develop a simple and accurate spectrophotometric method for the determination of mefenamic acid based on the oxidation of mefenamic acid with cerium (IV) ion, and the produced cerium (III) ion is subsequently reacted with arsenazo (III) reagent in acidic medium to form highly coloured complex.

\section{EXPERIMENTAL}

All spectrophotometric measurements are performed on Shimadzu UV-visible recording spectrophotometer UV-160 using 1-cm silica cells. pH meter type Philips PW 9420 is used for $\mathrm{pH}$ reading.

\section{Reagents}

All chemicals used are of analytical - reagent grade.

Standard mefenamic acid solution, $100 \mu \mathrm{g} \cdot \mathrm{ml}^{-1}$. This solution is prepared by dissolving $0.01 \mathrm{~g}$ of pure mefenamic acid (SDI- Iraq) in a solution of sodium hydroxide $(0.1 \mathrm{~N})$ containing $5 \mathrm{ml}$ ethanol and the volume is diluted to $100 \mathrm{ml}$ with sodium hydroxide $(0.1 \mathrm{~N})$ in a volumetric flask. This solution was further diluted to $10 \mu \mathrm{g}$. $\mathrm{ml}^{-1}$ with distilled water.

Ammonium ceric sulphate [cerium(IV) ion solution], $6.6 \times 10^{-5} \mathrm{M}$. This solution is daily prepared by dissolving $0.0105 \mathrm{~g}$ of ammonium ceric sulphate dihydrate (BDH) in $250 \mathrm{ml}$ of distilled water in a volumetric flask.

Arsenazo III reagent solution, $\mathbf{2} \times \mathbf{1 0}^{-4} \mathbf{M}$. This solution is prepared by dissolving $0.0411 \mathrm{~g}$ of arsenazo III (Fluka) in $250 \mathrm{ml}$ distilled water in a volumetric flask.

Hydrochloric acid solution, $0.05 \mathrm{~N}$. This solution is prepared by appropriate dilution of $4.2 \mathrm{ml}$ of the concentrated hydrochloric acid $(11.8 \mathrm{~N})$ solution to $100 \mathrm{ml}$ with distilled water in a volumetric flask.

Buffer solution, pH 3. This solution is prepared by mixing $50 \mathrm{ml}$ of $0.1 \mathrm{~N}$ glycine solution $(0.3752 \mathrm{~g}$ glycine dissolved in $50 \mathrm{ml}$ distilled water) with $5.7 \mathrm{ml}$ of $0.2 \mathrm{~N} \mathrm{HCl}$, then the volume is completed to $100 \mathrm{ml}$ with distilled water and adjusted to $\mathrm{pH} 3$ by $\mathrm{pH}$ meter.

\section{Procedure and calibration graph}

To a series of $25-\mathrm{ml}$ calibrated flasks, an increasing volume $(0.1-1.8 \mathrm{ml})$ of $10 \mu \mathrm{g} . \mathrm{ml}^{-1}$ mefenamic acid solution are transferred to cover the range of calibration graph, followed by $9 \mathrm{ml}$ of $6.6 \times 10^{-5} \mathrm{M}$ cerium (IV) ion solution and $0.9 \mathrm{ml}$ of $0.05 \mathrm{~N} \mathrm{HCl}$, the solutions are left for 25 minutes at room temperature, followed by addition of $2 \mathrm{ml}$ of $2 \times 10^{-4} \mathrm{M}$ arsenazo (III) reagent solution then $3 \mathrm{ml}$ of $\mathrm{pH} 3$ was added and diluted to the mark with distilled water, the absorbances are measured at $654 \mathrm{~nm}$ against the reagent blank. Beer's law is obeyed over the range of concentration 1 to $10 \mu \mathrm{g}$ mefenamic acid in $25 \mathrm{ml}$ (Fig. 1). A negative deviation from Beer's law is occurred beyond the upper determination limit. The apparent molar absorptivity, referred to mefenamic acid, has been found to be $1.731 \times 10^{5} 1 . \mathrm{mol}^{-1} . \mathrm{cm}^{-1}$. 


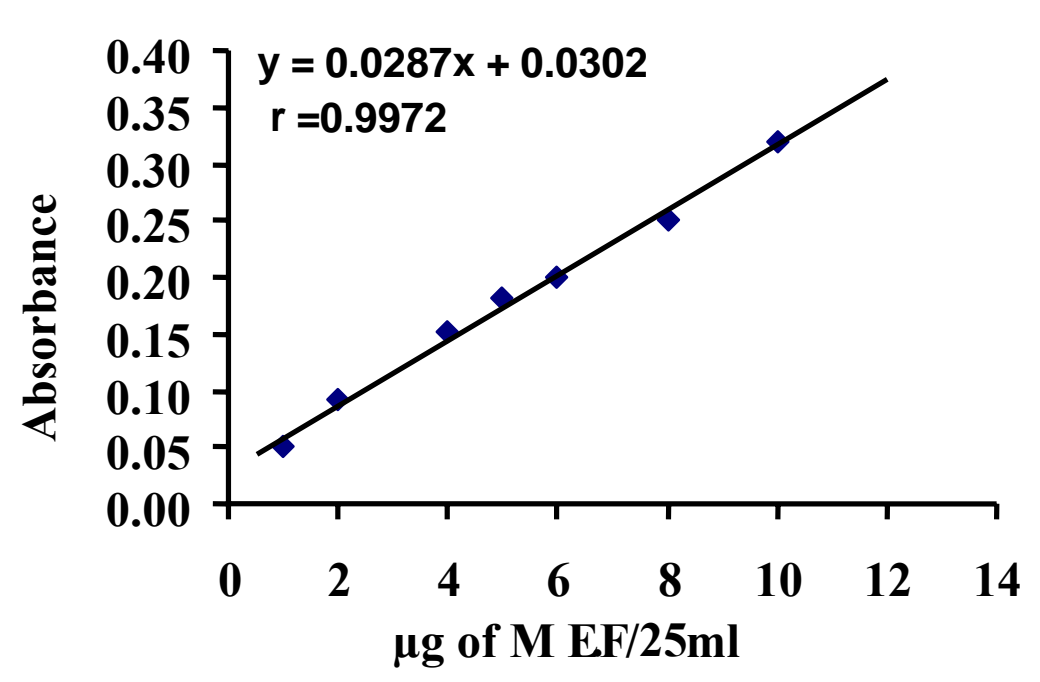

Fig. 1:Calibration graph for mefenamic acid determination using the reaction between arsenazo(III) and cerium(III).

Determination of mefenamic acid in capsule. Weight and mix the contents of five capsule (each one contains $250 \mathrm{mg}$ mefenamic acid), an accurately weighed amount of powder equivalent to $0.01 \mathrm{~g}$ mefenamic acid is dissolved in a mixture of $5 \mathrm{ml}$ ethanol and $75 \mathrm{ml}$ of $0.1 \mathrm{~N} \mathrm{NaOH}$, after filtration the filtrate is completed to $100 \mathrm{ml}$ with a $0.1 \mathrm{~N}$ $\mathrm{NaOH}$ in a volumetric flask. A $10 \mathrm{ml}$ of the above solution is diluted to $100 \mathrm{ml}$ to prepare $10 \mu \mathrm{g} \mathrm{ml} \mathrm{m}^{-1}$. A suitable aliquot of solution was taken and the recommended procedure was followed for analysis of the drug.

Determination of mefenamic acid in suspension. The content of the container $(100 \mathrm{ml}$, each $5 \mathrm{ml}$ contains $50 \mathrm{mg}$ mefenamic acid) is dissolved in a mixture containing $25 \mathrm{ml}$ of ethanol and $100 \mathrm{ml}$ of $0.1 \mathrm{~N} \mathrm{NaOH}$ then the solution is warmed, then filtered and the volume is completed to $250 \mathrm{ml}$ with $0.1 \mathrm{~N} \mathrm{NaOH}, 2.5 \mathrm{ml}$ which is equivalent to $0.01 \mathrm{~g}$ mefenamic acid is transferred into a $100 . \mathrm{ml}$ calibrated flask and the volume is completed with a distilled water. A $10 \mathrm{ml}$ of the above solution is diluted to $100 \mathrm{ml}$ to prepare $10 \mu \mathrm{g}$ $\mathrm{ml}^{-1}$ solution. A suitable aliquot of solution was taken and the recommended procedure was followed for analysis of the drug.

\section{Absorption spectra}

\section{RESULTS AND DISCUSSION}

Absorption spectrum of the coloured complex formed from the reaction between cerium (III) ion with arsenazo (III) in acidic medium against its corresponding reagent blank shows maximum absorption at $654 \mathrm{~nm}$ in contrast to the arsenazo reagent blank (Fig. 2). 


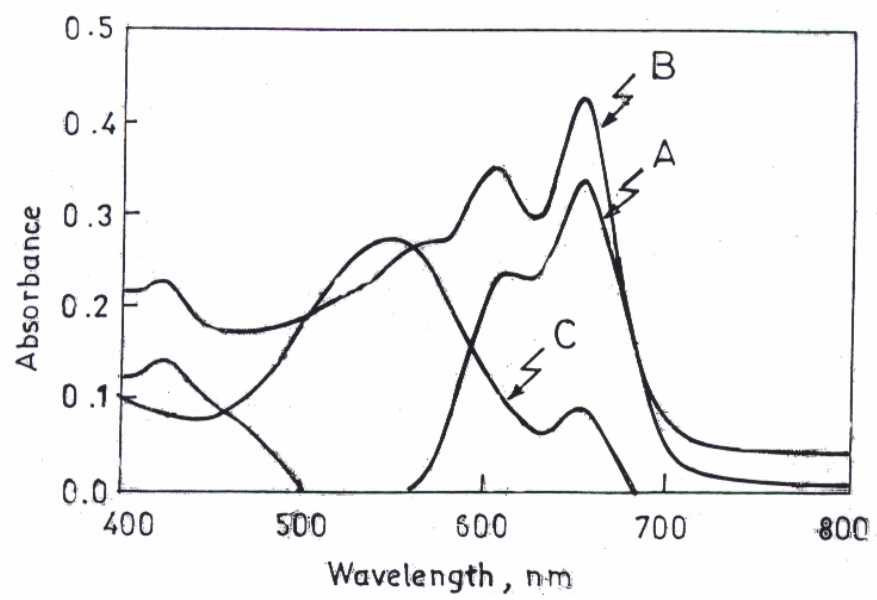

Fig.2:Absorption spectra of $10 \mu \mathrm{g}$ mefenamic acid / $25 \mathrm{ml}$ treated according to the recommended procedure and measured against (A) blank, (B) distilled water and $(\mathrm{C})$ blank measured against distilled water.

\section{Optimization of reaction conditions}

The effect of various parameters on the absorption intensity of the coloured complex containing $10 \mu \mathrm{g}$ of mefenamic acid is studied and the reaction condition have been optimized.

\section{Effect of pH}

The effect of $\mathrm{pH}$ on the intensity of coloured complex is examined. Different volumes $0-3 \mathrm{ml}$ of $0.05 \mathrm{M}$ hydrochloric acid solution is added to an aliquot of solution containing $10 \mu \mathrm{g}$ of mefenamic acid. The intensities of absorption were measured against the reagent blank at $654 \mathrm{~nm}$. The results are shown in Table 1.

Table 1: Effect of $\mathrm{pH}$ on absorbance

\begin{tabular}{|c|c|c|}
\hline ml of 0.05N HCl & Absorbance & Final pH \\
\hline 0.00 & 0.031 & 9.43 \\
\hline 0.1 & 0.077 & 6.11 \\
\hline 0.3 & 0.207 & 4.13 \\
\hline 0.5 & 0.213 & 3.50 \\
\hline 0.7 & 0.217 & 3.39 \\
\hline 0.8 & 0.220 & 3.30 \\
\hline 0.9 & 0.223 & 3.09 \\
\hline 1 & 0.221 & 2.98 \\
\hline 3 & 0.218 & 2.71 \\
\hline
\end{tabular}

The results shown in Table 1 indicate that the $\mathrm{pH}$ of $3.09(0.9 \mathrm{ml}$ of $0.05 \mathrm{~N} \mathrm{HCl})$ is considered optimum. A pH 3 is selected for subsequent investigation because of good sensitivity. Five buffer solutions of $\mathrm{pH} 3$ with different composition have been tested, tartaric acid- $\mathrm{NaOH}\left(\mathrm{B}_{1}\right)$, citric acid- $\mathrm{NaOH}\left(\mathrm{B}_{2}\right), \mathrm{KH}$ phthalate- $\mathrm{HCl}\left(\mathrm{B}_{3}\right)$, glycine- $\mathrm{HCl}$

$\left(\mathrm{B}_{4}\right)$ and formic acid-NaOH $\left(\mathrm{B}_{5}\right)$ (Table2). 
Table 2: Effect of buffer solution without and with hydrochloric acid on absorbance

\begin{tabular}{|c|c|c|c|c|c|c|}
\hline \multirow{2}{*}{$\begin{array}{c}\text { ml of Buffer } \\
\text { solution }\end{array}$} & \multirow{2}{*}{ Variable } & \multicolumn{5}{|c|}{ Absorbance/ml of Buffer added } \\
\cline { 3 - 7 } 2 & $\begin{array}{c}\text { Without } \\
\mathrm{HCl}\end{array}$ & -0.049 & -0.002 & 0.022 & 0.024 & -0.049 \\
\hline \multirow{2}{*}{3} & With HCl & 0.143 & 0.125 & 0.203 & 0.213 & 0.194 \\
\hline \multirow{2}{*}{4} & $\begin{array}{c}\text { Without } \\
\mathrm{HCl}\end{array}$ & -0.046 & 0.020 & 0.024 & 0.025 & -0.098 \\
\cline { 2 - 7 } & With HCl & 0.128 & 0.111 & 0.208 & 0.218 & 0.206 \\
\hline & $\begin{array}{c}\text { Without } \\
\mathrm{HCl}\end{array}$ & -0.044 & 0.001 & 0.014 & 0.019 & -0.066 \\
\cline { 2 - 7 } & With HCl & 0.130 & 0.102 & 0.154 & 0.202 & 0.188 \\
\hline $\begin{array}{c}\text { Final pH of } \\
\text { reaction } \\
\text { mixture }\end{array}$ & $\begin{array}{c}\mathrm{HCl}+ \\
\text { buffer }\end{array}$ & $3.02-3.10$ & $2.87-3.0$ & $3.13-3.15$ & $2.95-3.20$ & $3.22-3.34$ \\
\hline
\end{tabular}

The results shown in Table 2 indicate that all types of buffer solutions decrease the intensity of the coloured complex, but the results improved when buffer solution added after adding $0.9 \mathrm{ml} 0.05 \mathrm{~N} \mathrm{HCl} .3 \mathrm{ml}$ of glycine- $\mathrm{HCl}$ buffer solution (B4) is recommended in the subsequent experiments according to the highest intensity of the complex and it produces more stable complex (Table 3 ).

Table 3: The stability of complex without and with buffer solution

\begin{tabular}{|c|c|c|c|c|c|c|c|}
\hline Time (minute) & 0 & 5 & 10 & 15 & 20 & 25 & 35 \\
\hline Absorbance(A*) & 0.217 & 0.212 & 0.207 & 0.198 & 0.190 & 0.183 & 0.176 \\
\hline Absorbance(B**) & 0.223 & 0.220 & 0.220 & 0.217 & 0.217 & 0.216 & 0.216 \\
\hline
\end{tabular}

*Using hydrochloric acid only.

** Using $\mathrm{HCl}+3 \mathrm{ml}$ of glycine- $\mathrm{HCl}$

\section{Effect of oxidizing agent [cerium(IV) ion] amount}

The effect of cerium (IV) ion concentration on the absorbance of the complex was studied. It was found that $9 \mathrm{ml}$ of $6.6 \times 10^{-5} \mathrm{M}$ of $\mathrm{Ce}(\mathrm{IV})$ gave maximum absorption which is recommended in subsequent experiments (Table 4).

Table 4: The effect of ceric ion amount on absorbance

\begin{tabular}{|c|c|c|c|c|c|c|c|}
\hline \multirow{2}{*}{$\begin{array}{c}\text { ml of } \\
6.6 \times 10^{-5} \mathrm{M} \\
\mathrm{Ce}(\mathrm{IV}) \\
\text { Solution }\end{array}$} & \multicolumn{5}{|c|}{$\begin{array}{c}\text { Absorbance/ } \boldsymbol{\mu g} \text { of mefenamic acid } \\
\text { present }\end{array}$} & \multirow{2}{*}{$\begin{array}{l}\text { Absor- } \\
\text { bance } \\
\text { of } \\
\text { blank }\end{array}$} & \multirow{2}{*}{$\begin{array}{l}\text { Correlation } \\
\text { coefficient(r) }\end{array}$} \\
\hline & 2 & 4 & 6 & 8 & 10 & & \\
\hline 4 & 0.084 & 0.123 & 0.147 & 0.164 & 0.182 & 0.042 & 0.9829 \\
\hline 5 & 0.099 & 0.136 & 0.171 & 0.187 & 0.209 & 0.048 & 0.9864 \\
\hline 6 & 0.093 & 0.139 & 0.170 & 0.191 & 0.213 & 0.064 & 0.9847 \\
\hline 7 & 0.099 & 0.141 & 0.175 & 0.203 & 0.221 & 0.087 & 0.9890 \\
\hline 8 & 0.119 & 0.170 & 0.222 & 0.239 & 0.291 & 0.085 & 0.9897 \\
\hline 9 & 0.116 & 0.191 & 0.237 & 0.285 & 0.323 & 0.099 & 0.9917 \\
\hline 10 & 0.121 & 0.189 & 0.246 & 0.260 & 0.316 & 0.117 & 0.9817 \\
\hline
\end{tabular}




\section{Effect of time on reduction of cerium (IV) ion}

The effect of time needed to complete the reduction of cerium (IV) ions to cerium (III) ions was studied by standing of the solutions after adding cerium (IV) ion solution for different times at room temperature, then the other reagents were added and the absorbances were measured against the reagent blank (Table 5).

Table 5: Effect of time on reduction process

\begin{tabular}{|c|c|c|c|c|c|c|c|}
\hline Time (min.) & 0 & 10 & 20 & 25 & 30 & 35 & 40 \\
\hline Absorbance & 0.073 & 0.256 & 0.291 & $\underline{0.319}$ & 0.320 & 0.323 & 0.324 \\
\hline
\end{tabular}

The results indicate that complete reduction of cerium (IV) ions needed 25 minutes and the increase in intensity at 30 minutes and above is considered tolerable from that at 25 minutes. Therefore, the standing time 25 minutes was recommended for the subsequent experiments.

\section{Effect of arsenazo III reagent amount}

The effect of the amount of arsenazo III (AzIII) reagent on maximum formation of the coloured complex is investigated. The results are shown in Table 6.

Table 6: Effect of arsenazo III reagent amount on absorbance

\begin{tabular}{|c|c|c|c|c|c|c|}
\hline \multirow{2}{*}{$\begin{array}{c}\text { ml of AzII } \\
\text { Solution } \\
2 \times 10^{-4} \mathrm{M}\end{array}$} & \multicolumn{5}{|c|}{ Absorbance $/ \mu \mathrm{g}$ mefenamic acid } & \multirow[b]{2}{*}{$\mathbf{r}$} \\
\hline & 2 & 4 & 6 & 8 & 10 & \\
\hline 1 & 0.103 & 0.199 & 0.236 & 0.273 & 0.291 & 0.9543 \\
\hline 2 & 0.120 & 0.183 & 0.240 & 0.283 & 0.325 & 0.9955 \\
\hline 3 & 0.109 & 0.179 & 0.234 & 0.274 & 0.312 & 0.9908 \\
\hline 4 & 0.110 & 0.175 & 0.241 & 0.263 & 0.301 & 0.9809 \\
\hline
\end{tabular}

The results shown in Table 6 indicate that $2 \mathrm{ml}$ of arsenazo (III) reagent solution give higher sensitivity and higher value of correlation coefficient (r), therefore it has been selected for subsequent experiments.

\section{Effect of order of addition of reagents}

The effect of order of addition of reagents on the absorbance of coloured complex is investigated (Table 7).

Table 7: The order of addition of reagents

\begin{tabular}{|c|c|c|}
\hline Reaction component & Order number & Absorbance \\
\hline $\mathrm{MEF}+\mathrm{O}+\mathrm{A}+\mathrm{B}+\mathrm{R}$ & I* & 0.322 \\
\hline $\mathrm{MEF}+\mathrm{O}+\mathrm{B}+\mathrm{A}+\mathrm{R}$ & II & 0.099 \\
\hline $\mathrm{MEF}+\mathrm{O}+\mathrm{R}+\mathrm{A}+\mathrm{B}$ & III & 0.174 \\
\hline $\mathrm{MEF}+\mathrm{O}+\mathrm{R}+\mathrm{B}+\mathrm{A}$ & IV & 0.057 \\
\hline
\end{tabular}

* Mefenamic acid (MEF) $+\mathrm{Ce}^{+4}(\mathrm{O})+\mathrm{HCl}(\mathrm{A})+$ Buffer solution (B) + Arsenazo (III) (R)

The results indicate that the order of addition of reagents should be followed as given under procedure (order I). 


\section{Effect of Time}

The effect of time on the development and stability of the coloured complex for different amounts of mefenamic acid was investigated under the optimum experimental conditions established. The colour formation occurs immediately after the addition of all reaction mixtures and the absorbance of the complex remains constant for at least 1 hour (Table 8).

Table 8: Effect of time on the absorbance of complex

\begin{tabular}{|c|c|c|c|}
\hline \multirow{2}{*}{$\begin{array}{c}\text { Time/ } \\
\text { Minute }\end{array}$} & \multicolumn{3}{|c|}{ Absorbance / $\boldsymbol{\mu g}$ of Mefenamic acid in $\mathbf{2 5} \mathbf{~ m l}^{*}$} \\
\cline { 2 - 4 } & 4 & 8 & 10 \\
\hline 0 & 0.199 & 0.270 & 0.327 \\
\hline 5 & 0.199 & 0.270 & 0.327 \\
\hline 10 & 0.199 & 0.270 & 0.326 \\
\hline 15 & 0.199 & 0.270 & 0.325 \\
\hline 20 & 0.201 & 0.269 & 0.325 \\
\hline 25 & 0.201 & 0.269 & 0.325 \\
\hline 30 & 0.201 & 0.269 & 0.324 \\
\hline 35 & 0.201 & 0.269 & 0.322 \\
\hline 40 & 0.201 & 0.269 & 0.322 \\
\hline 45 & 0.201 & 0.269 & 0.322 \\
\hline 50 & 0.201 & 0.269 & 0.322 \\
\hline 55 & 0.201 & 0.269 & 0.320 \\
\hline 60 & 0.201 & 0.269 & 0.320 \\
\hline
\end{tabular}

*After 25 minutes reaction time of mefenamic acid with Ce (IV) ion.

The above stability period is sufficient to allow several measurements to be performed sequentially.

\section{Effect of interferences}

The effect of some foreign compounds which often accompanied pharmaceutical preparations are studied by adding three different amounts $(100,500$ and $1000 \mu \mathrm{g})$ to 10 $\mu \mathrm{g}$ of mefenamic acid in a final volume $25 \mathrm{ml}$ (Table 9).

Table 9: Effect of foreign compounds for assay of mefenamic acid

\begin{tabular}{|c|c|c|c|}
\hline \multirow{2}{*}{$\begin{array}{c}\text { Foreign } \\
\text { compound }\end{array}$} & \multicolumn{3}{|c|}{ Recovery(\%) of mefenamic acid per $\boldsymbol{\mu g}$ foreign added } \\
\cline { 2 - 4 } & 100 & 500 & 1000 \\
\hline Glucose & 98.9 & 102.7 & 100 \\
\hline Lactose & 103.1 & 104.1 & 100 \\
\hline Starch & 104.1 & 104.8 & 103.7 \\
\hline Arabic gum & 97.5 & 92.9 & 91.7 \\
\hline
\end{tabular}


The results in Table 9 indicated that the studied foreign compounds did not interfere in the determination of mefenamic acid by using the proposed method except Arabic gum at high concentration.

\section{Accuracy and precision}

To check the accuracy and precision of the calibration graph, mefenamic acid was determined at three different concentrations. The results shown in Table 10 indicate that the calibration graph is satisfactory.

Table 10: Accuracy and precision

\begin{tabular}{|c|c|c|}
\hline $\begin{array}{c}\text { Amount of MEF } \\
\text { taken }, \boldsymbol{\mu g}\end{array}$ & $\begin{array}{c}\text { Relative error, } \\
\mathbf{\%}^{*}\end{array}$ & $\begin{array}{c}\text { Relative Standard } \\
\text { deviation, \%* }\end{array}$ \\
\hline $\mathbf{2}$ & 1.65 & 1.90 \\
\hline $\mathbf{5}$ & 0.93 & 1.26 \\
\hline $\mathbf{1 0}$ & -0.92 & 1.56 \\
\hline
\end{tabular}

*Average of five determinations

\section{Nature of the reaction between mefenamic acid and cerium(IV) ion}

Job's method was used in the determination of the reaction ratio of mefenamic acid with cerium (IV) ion. The results obtained (Fig. 3) showed that a 1:1 mefenamic acid to cerium (IV) ion ratio is obtained.

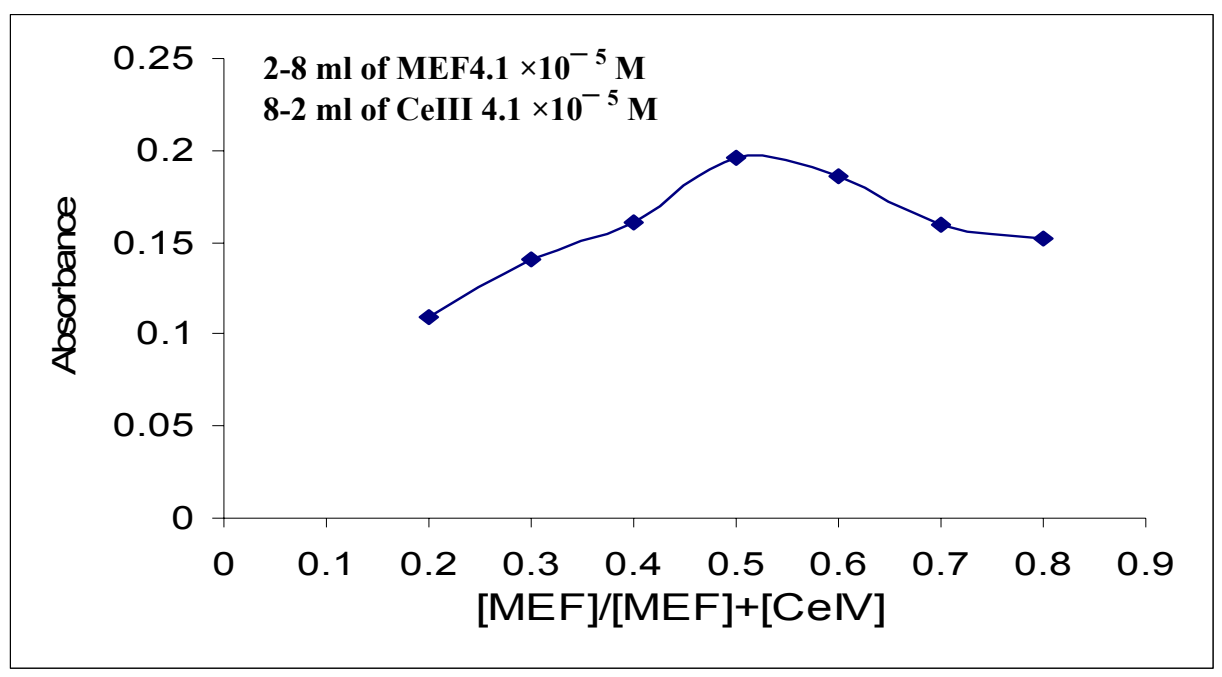

Fig.3: Job's plot for mefenamic acid -cerium (IV) ion 
The probable mechanism of the reaction might be the following:<smiles>Cc1cccc(Nc2ccccc2C(=O)O)c1C</smiles>
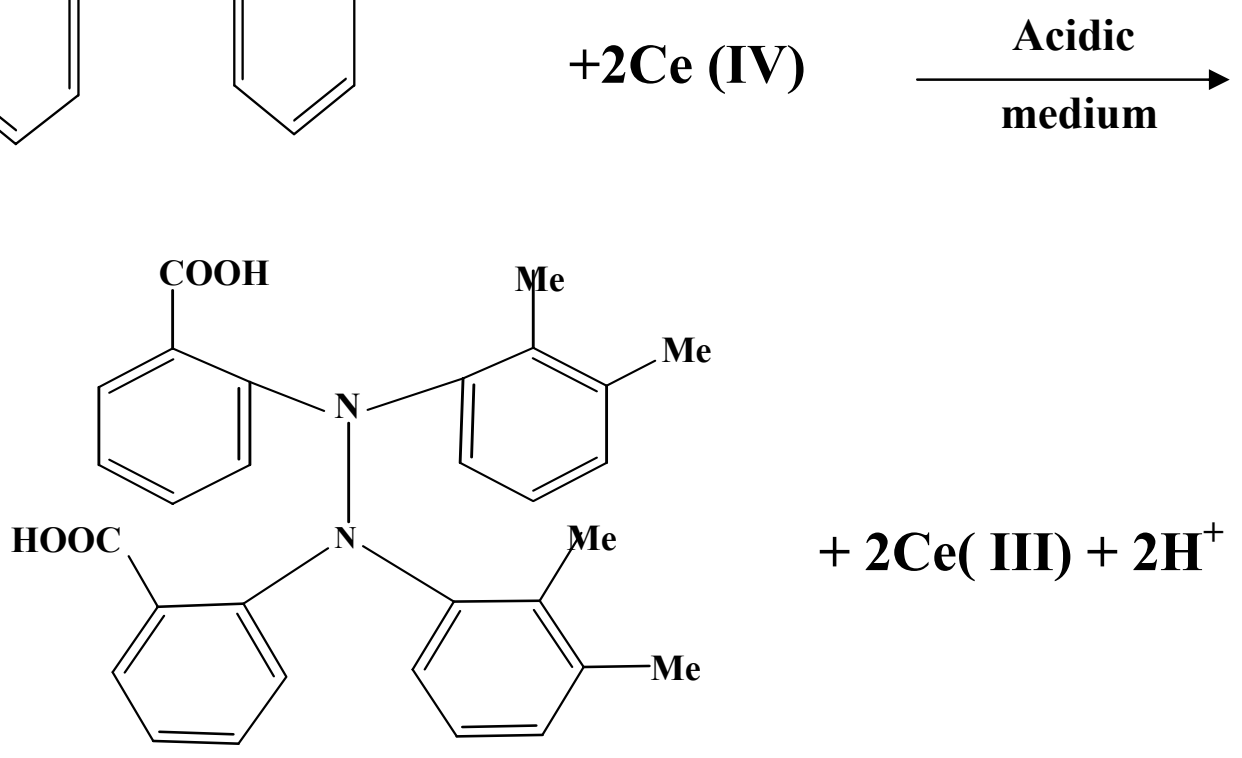

\section{Nature of arsenazo (III)-cerium (III) ion complex}

The stoichiometry of arsenazo III and cerium ion, the reaction is investigated using the Job's method under the optimized conditions. The results obtained (Fig. 4) showed that a $1: 1$ arsenazo (III) to cerium (III) ion ratio is obtained.

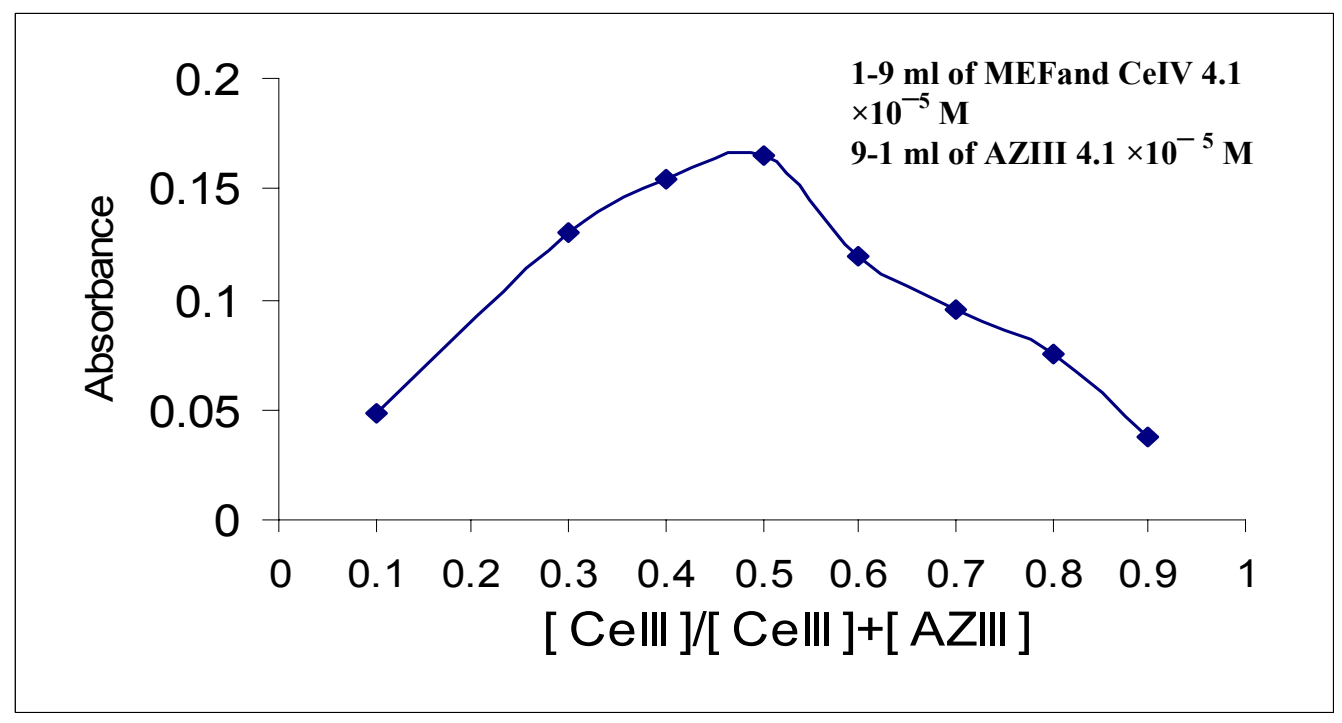

Fig. 4: Job's plot for arsenazo III-cerium (III) ion complex 


\section{Analytical applications}

The proposed method was applied to determine mefenamic acid in different pharmaceutical preparations. On applying proposed procedure, good recoveries were obtained as shown in Table 11.

Table 11: Analytical applications

\begin{tabular}{|c|c|c|c|}
\hline Pharmaceutical preparation & $\begin{array}{c}\boldsymbol{\mu g} \text { mefenamic acid } \\
\text { present/25ml }\end{array}$ & $\begin{array}{c}\boldsymbol{\mu g} \text { mefenamic acid } \\
\text { measured/25ml }\end{array}$ & $\begin{array}{c}\text { Recovery( } \\
\mathbf{\%})\end{array}$ \\
\hline Ponstidin capsule(250 mg) & 5 & 4.98 & 99.6 \\
\cline { 2 - 4 } N.D.I-Iraq & 10 & 9.87 & 98.7 \\
\hline $\begin{array}{c}\text { Ponstidin capsule(250 mg) } \\
\text { GMBH,Germany }\end{array}$ & 5 & 4.82 & 96.4 \\
\hline $\begin{array}{c}\text { Mefastan (50 mg/5 ml) } \\
\text { Al-Anaam pharma-Ind. } \\
\text { (Baghdad-Iraq) }\end{array}$ & 10 & 9.87 & 98.7 \\
\cline { 2 - 4 } & 10 & 5.14 & 102.8 \\
\hline
\end{tabular}

\section{Evaluation of the proposed method}

The performance of the proposed method is assessed by calculating the student s $\mathrm{t}-$ test compared with the standard method (British Pharmacopoeia, 2000). At the 95\% confidence limit for four degree of freedom, the calculated $t$ - values do not exceed the theoretical value (2.776). The results in Table 12 indicate that there is no significant difference between the proposed method and the standard method.

Table 12: Analysis of mefenamic acid in pharmaceuticals by proposed and official method

\begin{tabular}{|c|c|c|c|}
\hline \multirow{2}{*}{ Drug } & \multicolumn{2}{|c|}{ Recovery, (\%)* } & \multirow{2}{*}{ t-exp. } \\
\cline { 2 - 3 } & Present method & Official method & \multirow{2}{*}{$\begin{array}{c}\text { (\%) } \\
\text { Ponstidin capsule(250 mg) } \\
\text { N.D.I-Iraq }\end{array}$} \\
$\begin{array}{c}\text { Ponstidin capsule(250 mg) } \\
\text { GMBH,Germany }\end{array}$ & 97.10 & 100 & 1.904 \\
\hline
\end{tabular}

*Average of five determinations

Standard addition method has been used in determination two of drugs under investigation in order to prove that the proposed method is applied to the determination of mefenamic acid without interferences (Table 13 and Fig. 5).

Table 13: The results of standard addition method

\begin{tabular}{|c|c|c|c|}
\hline $\begin{array}{c}\text { Pharmaceutical } \\
\text { preparation }\end{array}$ & $\begin{array}{c}\mu \mathbf{g} \text { mefenamic } \\
\text { acid } \\
\text { present/25ml }\end{array}$ & $\begin{array}{c}\mu \mathbf{g} \text { mefenamic } \\
\text { acid } \\
\text { measured/25ml }\end{array}$ & $\begin{array}{c}\text { Recovery } \\
* \\
\mathbf{( \% )}\end{array}$ \\
\hline Ponstidin capsule(250 mg) & 2 & 2.02 & 101.0 \\
\cline { 2 - 4 } N.D.I-Iraq & 4 & 4.00 & 100.0 \\
\hline $\begin{array}{c}\text { Mefastan (50 mg/5 ml) } \\
\text { Al-Anaam pharma-Ind. } \\
\text { (Baghdad-Iraq) }\end{array}$ & 2 & 2.05 & 102.5 \\
\cline { 2 - 4 } & 4 & 4.00 & 100.0 \\
\hline
\end{tabular}

*Average of three determinations 

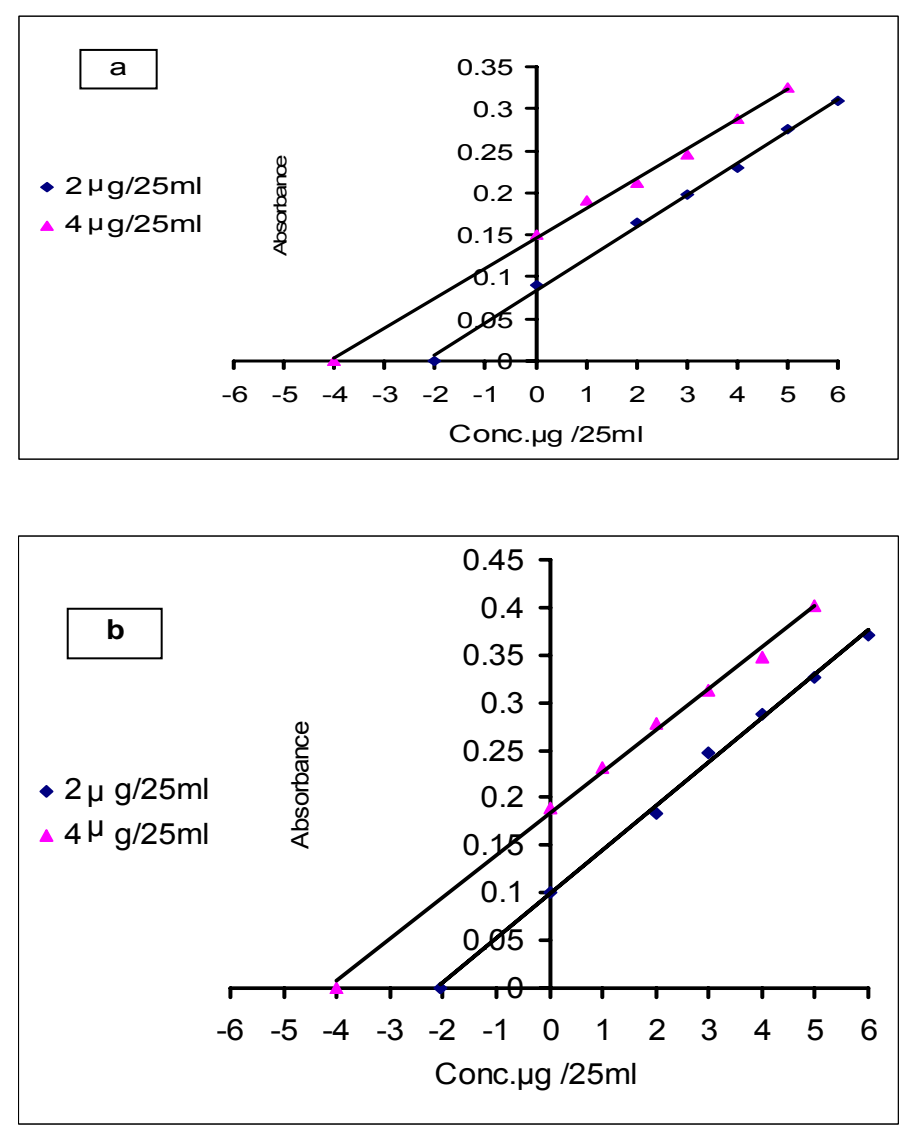

Fig.5. Graphs of standard addition method for the determination of mefenamic acid in Ponstidin capsule (250 mg) N.D.I-Iraq (a) and on Mefastan $(50 \mathrm{mg} / 5 \mathrm{ml})$ AlAnaam pharma.-Ind. (Baghdad-Iraq) (b)

The results in Table 13 and Fig. 5 indicated that the proposed method can be applied successfully to the determination of mefenamic acid in pharmaceutical formulations .

\section{COMPARISON OF THE METHODS}

Table 14 shows the comparison between some of analytical parameters of the present method with another recent spectrophotometric method. 
Table 14: The comparison of the methods

\begin{tabular}{|c|c|c|}
\hline Analytical parameters & $\begin{array}{l}\text { Present } \\
\text { method }\end{array}$ & Literature method* \\
\hline $\mathrm{pH}$ & 3 & Alkaline medium \\
\hline Temperature $\left({ }^{\circ} \mathrm{C}\right)$ & Room temperature & $30^{\circ} \mathrm{C}$ \\
\hline$\lambda_{\max }(\mathrm{nm})$ & 654 & 490 \\
\hline Medium of reaction & Aqueous & Non-aqueous \\
\hline Reagent & Arsenazo(III) & $\begin{array}{c}\text { 4-amino-3,5- } \\
\text { dinitrobenzoic acid }\end{array}$ \\
\hline Beer's law range (ppm) & $0.04-0.4$ & $1-6$ \\
\hline $\begin{array}{l}\text { Molar absorptivity } \\
\left(1 . \mathrm{mol}^{-1} \cdot \mathrm{cm}^{-1}\right)\end{array}$ & $1.634 \times 10^{5}$ & $1.558 \times 10^{4}$ \\
\hline RSD (\%) & $\leq 1.93$ & 1.37 \\
\hline $\begin{array}{l}\text { Stability of the colour } \\
\text { (minute) }\end{array}$ & 60 & ---- \\
\hline Colour of the product & Bluish green & Orange-red \\
\hline Application of the method & $\begin{array}{l}\text { Has been applied to the assay } \\
\text { of mefenamic acid in capsule } \\
\text { and in suspension solution }\end{array}$ & $\begin{array}{l}\text { Has been applied to the } \\
\text { assay of mefenamic acid } \\
\text { in capsule }\end{array}$ \\
\hline
\end{tabular}

* Idowut,S.,Adegoke,A. and Olaniyi,A.,2003.

The results in Table 14 show that the suggested method for the determination of mefenamic acid was sensitive and needs neither temperature control nor extraction step.

\section{CONCLUSION}

The proposed method for the determination of mefenamic acid in pharmaceutical preparations was sensitive. The complex formed was fairly soluble in aqueous solution. The statistical analysis of the results indicates that the method has good accuracy (average relative error between -0.92 to $+1.65 \%$ ) and good precision (average relative standard deviation not more than $1.93 \%$ ). The t-value indicates that there was no significant difference between the proposed method and the standard method. Moreover, the proposed method needs neither temperature control nor extraction step.

\section{REFERENCES}

Al-Abdaly, Z.Z., 2005. Spectrophotometeric Determination of p-Aminobenzoic AcidApplication to Pharmaceutical Preparations, M.Sc., Hesis, Mosul University, 61p. Albero, M., Sanchez, C., and Farcia, M., 1995. Flow-injection Spectrofluorimetric Determination of Flufenamic and Mefenamic, J.Pharm. Biomed .Anal., 13, pp. 1113-1117.

Al-Irhayim, A.N., 2004. Spectrophotomtric Assay of Isoniazide in Tablet, M.Sc., Thesis, Mosul University, 33p.

Aman, T., Asrar, A., and Mateen, B., 2005. Colorimetric Determination of Two Nonsteroidal Anti-inflammatory Drugs Using p-dimethylaminocinnamaldehyde Anal. let., 38, pp. 1899-1912.

British Pharmacopeia on CD-ROM, 3rd Edn., System Simulation Ltd, the Stationary Office, London, 2000.

Chilukuri, S., and Ambati, R., 1986. Spectrophotometric Determination of some Analgesic and Anti-inflammatory Agents with Methyl-2-Denzothiazolinone Hydrazone Hydrochloride, Mikrochimi.a Acta, 97, pp. 237-244. 
Dinc, E., Yucesoy, C., and Onur, F, 2002. Simultaneous Spectrophotometric Determination of Mefenamic Acid and Paracetamol in a Pharmaceutical Preparation Using Ratio Spectra Derivative Spectrophotometry and Chemometric Methods, J. Pharma. Biomed. Anal., 28, pp. 1091-1100.

EL-Sherif, Z., Walash, M., EL-Tarras, M., and Osman, A., 1997. Colorimetric Determination of Two Nonsteroidal Anti-inflammatory Drugs Using p-dimethylaminocinnamaldehyde, Anal.lett., 30, pp. 1881-1896.

Fatma, A., Aly; Salma, A., AL-Tamimi, and Abdulrahman A., ALwarthan, 2000. Determination of Flufenamic Acid and Mefenamic Acid in Pharmaceutical Preparations and Biological Fluids Using Flow Injection Analysis with Tris (2,2'-bipyridyl) Ruthenium (II) Chemiluminescence Detection, Anal. Chim. Acta, 416, pp. 87-96.

Garg, G., and Sarsf, S., 2007. Simultaneous Estimation of Mefenamic Acid and Ethamsylate in Tablets. Indian J. Pharm. Sci., 69, pp. 2-7.

Idowut, S., Adegoke, A., and Olaniyi, A., 2003. Novel Colorimetric Assay of Mefenamic Acid Using 4-Amino-3,5-Dinitrobenzoic Acid (ADBA), Tropical J. Pharm. Research, 1, pp. 15-22.

Ishidaka, O., Shinohara; T., Tanaka, T., and Momose, A., 1986. Determination of Mefenamic acid in Horse Plasma by High Performance Liquid Chromatography, Japan analyst, 35, pp. 332-334.

Jaime, N.D., and William, A.R., Wilson and Gisvold's, 1991. Text Book of Organic Medicinal and Pharmaceutical Chemistry, 9th Edn., J.B. Lippincott Company, London, 201p.

Martindale, 1982. The Extra Pharmacopoeia, 28th Edn., The Pharmaceutical Press, London. pp. 262-263.

Mohammed, R., Ali; A, Yalda, H., and Fakhredin, A., 2004. Liquid Chromatography Method for Determination of Mefenamic Acid in Human Serum. J. Chrom. B, 800, pp. 189-192.

Niopas, I., and Mamzoridi, k., 1994. Determination of Indomethacin and Mefenamic Acid in Plasma by High-performance Liquid Chromatography, J. Chromatogr. B, Biomed. Appl. 656, pp.447-450.

Pinelopi, C., Natalie, V., Dimitra, A., Kiriaki, G., and Georgia, M., 1998. SpectrofLuorimetric Determination of Anthranilic Acid Derivatives Based on Terbium Sensitized Fluorescence, Analyst, 123, pp.2839-2843.

Sastry, C., and Rao, A., 1987. Spectrophotometric Method for Determination of Pentazocine and Mefenamic acid, Indian J. Pharm. Sci., 49, pp. 95-96.

Tabrizi, A.B., 2006. Determination of Mefenamic Acid in Human Urine by Means of two Spectroscopic Methods by Using Cloud Point Extraction Methodology as a Tool for Treatment of Samples, Bull. Korean Chem. Soc., 27, pp. 1780-1784.

Tabrizi, A.B., 2006. A Simple Spectrofluorimetric Method for Determination of Mefenamic Acid in Pharmaceutical Preparation and Urine, Bull. Korean Chem. Soc., 27, pp.1199-1202.

Zommer, S., and Bojarowicz, H., 1986. Spectrofluorimetric Investigations on Protolytic Equilibria of Mefenamic Acid and Determination by Means Fe (III) in MethanolAqueous Media, J. Pharm. Biomed. Anal., 4, pp.475-481. 